\title{
Phyllosphere of Submerged Plants in Bathing Lakes as a Reservoir of Fungi-Potential Human Pathogens
}

\author{
Anna Biedunkiewicz $^{1}$ (D) Ewa Sucharzewska ${ }^{1} \cdot$ Kamila Kulesza $^{1} \cdot$ Karolina Nowacka $^{1} \cdot$ Dariusz Kubiak $^{1}$
}

Received: 14 July 2019 / Accepted: 27 September 2019 /Published online: 26 October 2019

(C) The Author(s) 2019

\begin{abstract}
This study analysed whether the littoral zone in the immediate vicinity of bathing sites retains potentially pathogenic yeasts on the phyllosphere surface and to what extent the species composition of microfungi in the phyllosphere and in surface waters is similar. The research was carried out in selected lakes located within the administrative boundaries of the city of Olsztyn, the largest city in the Masurian Lake District (NE Poland). The experiment was conducted in three summer seasons near bathing sites in three lakes, which are the most popular as recreational sites (Lake Kortowskie, Lake Tyrsko, and Lake Skanda). Microfungi isolated from the phyllosphere of 13 plant species of the littoral zone from dropped leaves of coast plants with no disease symptoms were used as the study material. The isolated fungi were identified in accordance with the accepted diagnostic procedures applied in mycological laboratories. A total of 36 yeast species of 16 genera were identified. Fungi found earlier at the bathing sites of the lakes were identified in $60 \%$ of the cases. Nine species were categorised as class BSL-2 fungi. This study provides a valuable complement of data concerning the natural composition of the littoral microbiota.
\end{abstract}

Keywords Phyllosphere $\cdot$ Littoral $\cdot$ Yeast $\cdot$ Potential pathogens $\cdot$ Sanitary and epidemiological hazard

$\begin{array}{ll}\text { Abbreviations } \\ \text { BSL } & \text { Biosafety level scale } \\ \text { S } & \text { Skanda Lake } \\ \text { K } & \text { Kortowskie Lake } \\ \text { T } & \text { Tyrsko lake } \\ \text { V } & \text { Microfungi species isolated from the phyllosphere } \\ \text { x } & \text { Microfungi species isolated from the water under } \\ & \text { study }\end{array}$

Introduction Studies conducted so far by these authors on taxonomic diversity and the population size of potentially pathogenic fungi in urban lakes concerned open areas and bathing sites, where water users may come into contact [1-4]. The very presence of microfungi, as well as their prevalence, depends on many environmental factors, such as: daily and seasonal changes of lighting and temperature and fluctuations of oxygen concentration resulting from accumulation of

Anna Biedunkiewicz

alibi@uwm.edu.pl

1 Department of Microbiology and Mycology, Faculty of Biology and Biotechnology, University of Warmia and Mazury in Olsztyn, Oczapowskiego 1A, 10-719 Olsztyn, Poland organic matter, usually of anthropogenic origin. These factors accelerate the decomposition of submerged parts of plants in the littoral zone, which creates a perfect environment for growth of microorganisms, including fungi. These could be auto- or allochthonous species, which enter shore waters not only with surface contamination, but also with household wastewater or industrial discharge [5]. This results in the littoral zone burden of nutrients and, in consequence, it accelerates water eutrophication [3]. Soil can also be an important source of microfungi; from it, they enter the water with surface or underground effluents.

The majority of mycological studies of aquatic plants usually concerned phytopathogenic fungi [6-12], endophytes and epiphytes causing leaf decomposition [13] or aquatic zoosporous fungi [14]. Only a few papers devoted to the phyllosphere of aquatic plants concern the presence of yeast important for sanitary and epidemiological reasons [15]. Conversely, the microbiota of crop leaves $[16,17]$ or tropical epiphytic species [18] is described much more frequently.

The constant presence of potentially pathogenic microfungi in the surface waters of bathing lakes, revealed by monitoring conducted by these and other authors $[3,4$, 19-21] and fragmentary reports concerning their presence in the aquatic plant phyllosphere encouraged us to take up a 
study of this ecological niche. The aim of the study was to determine whether the littoral zone in the immediate vicinity of bathing sites, with no disease symptoms, retains potentially pathogenic yeast on the phyllosphere surface and to what extent the species composition of microfungi in the phyllosphere and in surface waters is similar.

\section{Material and Methods}

The experiment was conducted in three summer seasons (2006-2011-2016) near the bathing sites in three lakes in Olsztyn: Kortowskie, Tyrsko and Skanda, which are the most popular as recreational sites. Microfungi isolated from the phyllosphere of 13 plant species of the littoral zone from dropped leaves of coast plants with no disease symptoms were the study material. Submerged parts of the same plants from each lake were used as follows: Phragmites australis L., Hydrocharis morsus-ranae L., Veronica beccabunga L., Nuphar lutea L., Stratioites aloides L., Persicaria amphibia L., Potamogeton natans L., Lemna minor L., Ceratophyllum demersum L., Urticularia vulgaris L., Myriophyllum sp. and dropped leaves of Alnus glutinosa L. and Acer platanoides L. Each season, the material was collected in late spring, summer, and early autumn three times, giving a total of 27 samples of vegetation. The material was taken along the shoreline in the immediate vicinity of places intended for recreationbathing areas. On Skanda and Tyrsko lakes, vegetation was collected on the northwestern shore of the lake, while on Kortowskie lake — on the south-eastern shore (Fig. 1).

Fragments of plants, with an area of ca. $1 \mathrm{~cm}^{2}$, were placed in Sabouraud agar and incubated at $37^{\circ} \mathrm{C}$ for $48-72 \mathrm{~h}$. The culture was watched for clouding, deposits or a membrane on the broth surface, which were symptoms of yeast presence. Five drops of $20 \mu \mathrm{l}$ were taken from each culture with visible microfungi growth and inoculated on solid Sabouraud agar with chloramphenicol $(0.05 \%)$ by the "one drop" method. The samples were incubated for $48-72 \mathrm{~h}$ at $37^{\circ} \mathrm{C}$. The colony growth was passaged onto slants with Sabouraud agar and subjected to a standard diagnostic analysis commonly applied in mycological laboratories. The following were evaluated: macroscopic features (colour, sheen, surface structure, growing into agar), microscopic features in microculture on Nickerson agar (presence and position of blastospores, chlamydospores, formation of pseudomycelium) and biochemical features (zymograms, carbohydrate auxanograms) [4]. Due to the adopted method of pure fungi culture, the number of $\mathrm{CFU} / \mathrm{dm}^{3}$ was not determined, but rather the observations were focused on differentiation and comparison of the species composition of the isolates with the results of studies conducted earlier in the same waters [1-3] during which a total of 212 water samples were taken for mycological analyses. The biosafety level (BSL) was determined for microfungi species $[22,23]$.
The species were identified with identification keys and studies: Kurtzman and Fell [24], Kurtzman et al. [25] and de Hoog et al. [23]. Photographic documentation was performed and the identified species were catalogued.

The significance of differences in the number of species between individual lakes was tested by means of the Kruskal-Wallis test followed by Dunn's test of multiple comparisons $(p<0.05)$. In turn, repeated measures ANOVA (Friedmann) and then $t$ test (Wilcoxon, $p<0.05$ ) were employed to check the significance of differences in the number of species between individual research seasons. The correlation between the prevalance of microfungi in water and in the phyllosphere was established by computing the Spearman's rank correlation coefficient. All statistical analyses were performed using STATISTICA 13 package (StatSoft).

\section{Results}

A total of 36 yeast species of 16 genera were identified. The largest number of microfungi species were found on Phragmites australis-29, and on Ceratophyllum demersum-15. The following dominated among yeasts: Candida krusei-found on seven plant species (Fig. 2), and Candida glabrata - on five plant species (Fig. 3). For the other plants, the number of fungi species observed varied between three and six or only individual observations were recorded (Table 1).

The species differentiation of microfungi associated with the littoral zone phyllosphere in the lakes under study was distinct and different in different water bodies. The largest number of fungi were found in the littoral zone of Lake Skanda (36 microfungi species), only slightly fewer were found in Lake Kortowskie ( 25 species) and the smallest number was found in Lake Tyrsko (11 species) (Table 2). Statistically significant differences were shown in the prevalence of yeast in the phyllosphere between samples from Skanda and Kortowskie lakes $(p=$ $0.0126)$ and Skanda and Tyrsko lakes $(p=0.000024)$. In contrast, no statistically significant differences were found between Kortowskie and Tyrsko lakes. Ph. australis fungi were recorded with the highest frequency in each of the lakes. Fungi species recorded in the surface water of the bathing sites under study were also identified in the phyllosphere in $60 \%$ of the cases. Positive correlations were found between the number of yeast isolated from lake water and from the phyllosphere (correlation coefficient 0.234 ). The same species in the phyllosphere and in bathing site waters were observed in 21 cases. Four fungi species are as follows: Candida albicans, C. guilliermondii, C. krusei, and Saccharomyces cerevisiae were isolated from all the lakes under study 


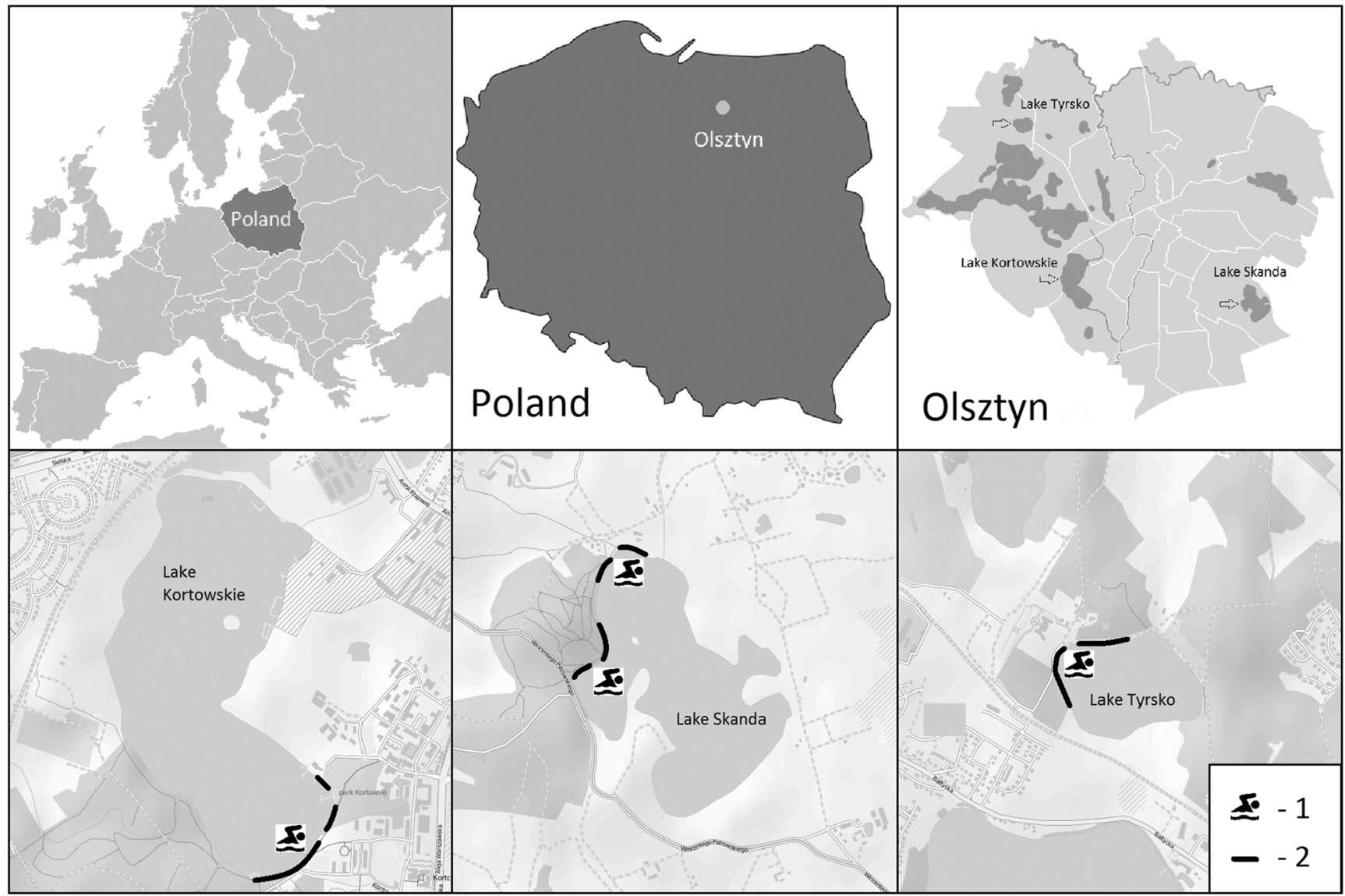

Fig. 1 The scheme of sampling sites localization

and from the phyllosphere (Table 2). The fungi were found with a different frequency in all seasons under study. Statistically significant differences in the prevalence of yeast in the phyllosphere were shown between the 2006 and 2011 seasons $(p=0.007)$ and 2003 and $2016(p=0.000032)$.

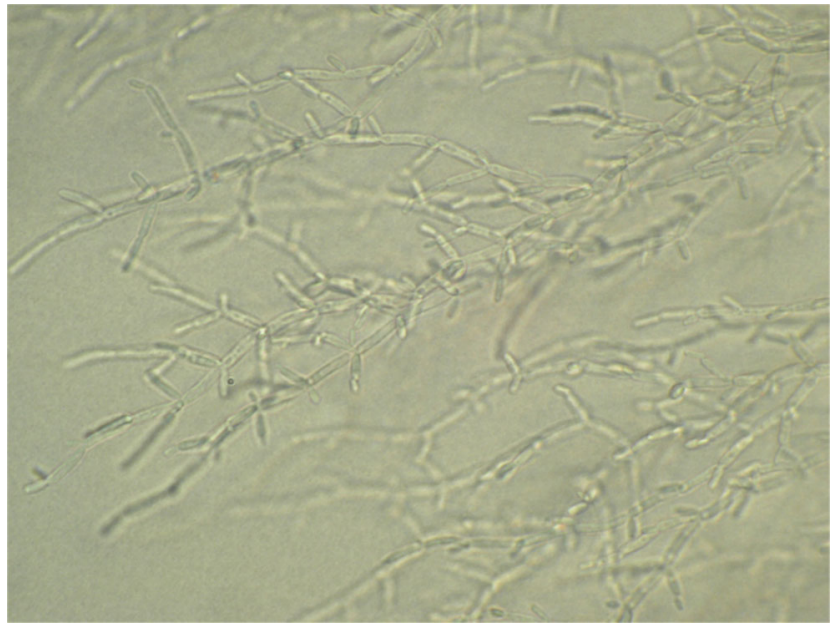

Fig. 2 Candida krusei - microculture on the agar Nickerson after $72 \mathrm{~h}$ of incubation (magn. $\times 600$ )
Of the microfungi species found, nine were classified as BSL-2 (i.e. potential pathogens) and four species as BSL-1 (i.e. saprotrophs). The other 23 species were not classified into any biosafety group (Table 1 ).

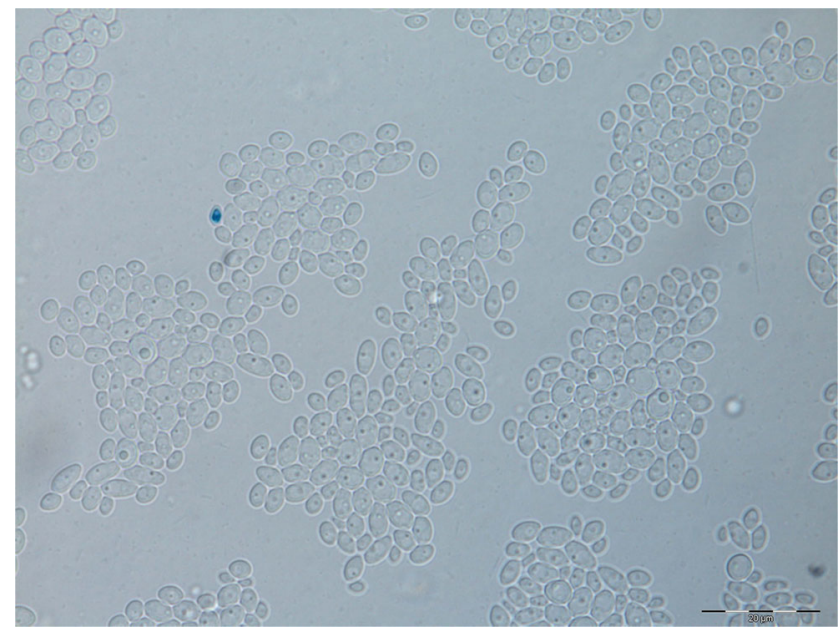

Fig. 3 Candida glabrata - microculture on the agar Nickerson after $72 \mathrm{~h}$ of incubation (magn. $\times 1000$ ) 

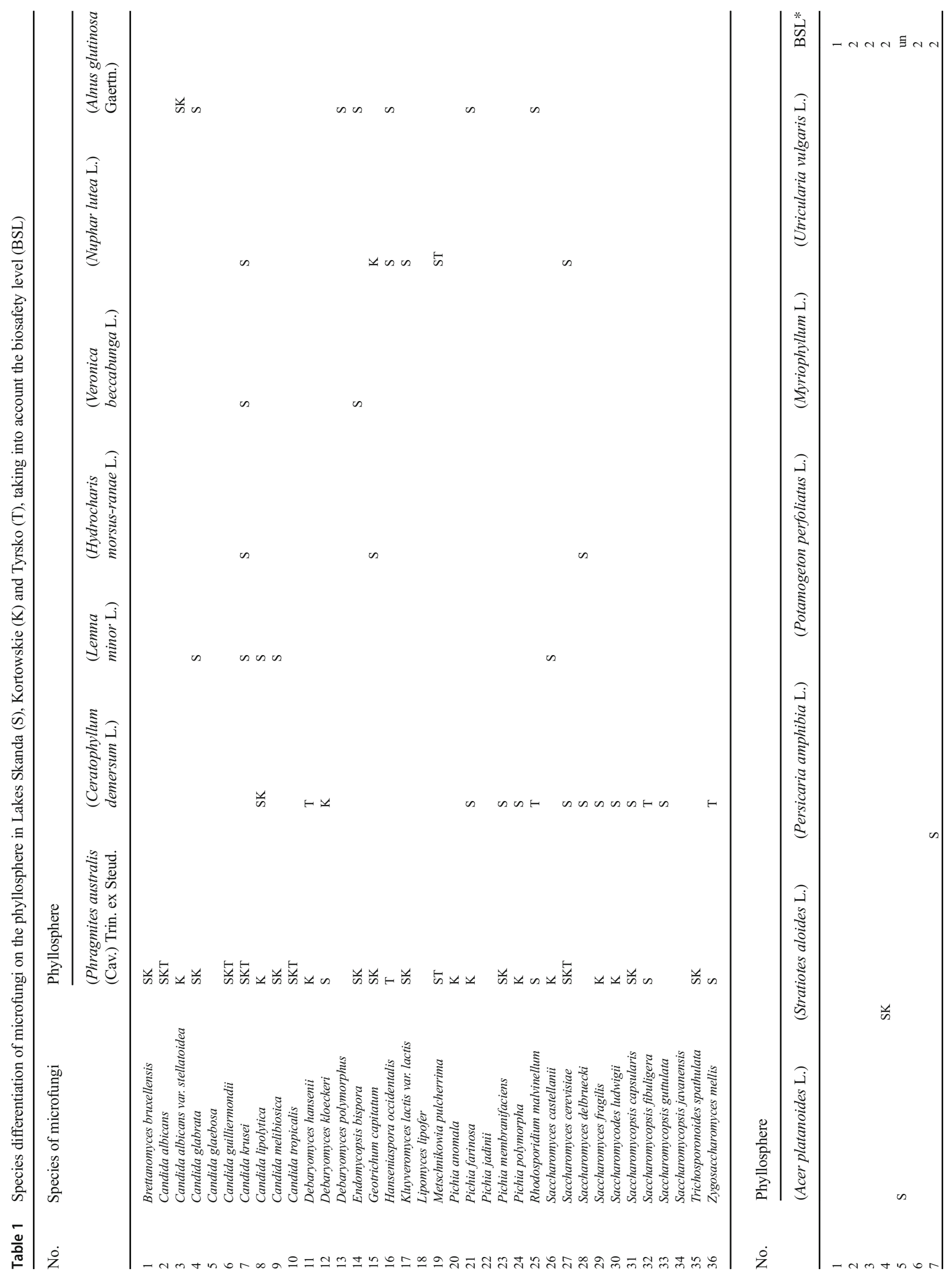


$$
[
$$


Table 2 List of microfungi species isolated from the phyllosphere (v) and those previously isolated from the water under study (x) [1-3]

No List of all the fungi species isolated from the lake water and from the phyllosphere
Skanda

Water Phyllosphere Water Phyllosphere Water Phyllosphere
1 Brettanomyces bruxellensis

2 Brettanomyces nanus*

3 Candida aaseri*

4 Candida albicans

5 Candida albicans var. stellatoidea

6 Candida glabrata

7 Candida glaebosa

8 Candida globosa

9 Candida guilliermondii (t: Meyerozyma guilliermondii)

10 Candida intermedia

11 Candida kruissii

12 Candida krusei (t: Pichia kudriavzevii)

13 Candida lipolytica

14 Candida melibiosica

15 Candida parapsilosis

16 Candida rugosa

17 Candida silvae

18 Candida solani

19 Candida suecica

20 Candida stellata

21 Candida tropicalis

22 Candida vini

23 Citeromyces matritensis

24 Cyniclomyces guttulatus

25 Cystofilobasidium infirmominiatum

26 Debaryomyces fabryi

27 Debaryomyces hansenii

28 Debaryomyces kloeckeri

29 Debaryomyces maramus

30 Debaryomyces polymorphus

31 Debaryomyces vini

32 Dipodascus armillariae

33 Dipodascus ovetensis

34 Endomycopsis bispora

35 Geotrichum capitatum

36 Hanseniaspora occidentalis

37 Hanseniaspora osmophila

38 Hanseniaspora valbyensis

39 Hansenula minuta

40 Kazachstania africana

41 Kazachstania lodderae

42 Kazachstania transvaalensis

43 Kloeckera africana

44 Kloeckera javanica

45 Kluyveromyces aestuarii

46 Kluyveromyces lactis var. lactis

47 Kluyveromyces marxianus

x V V

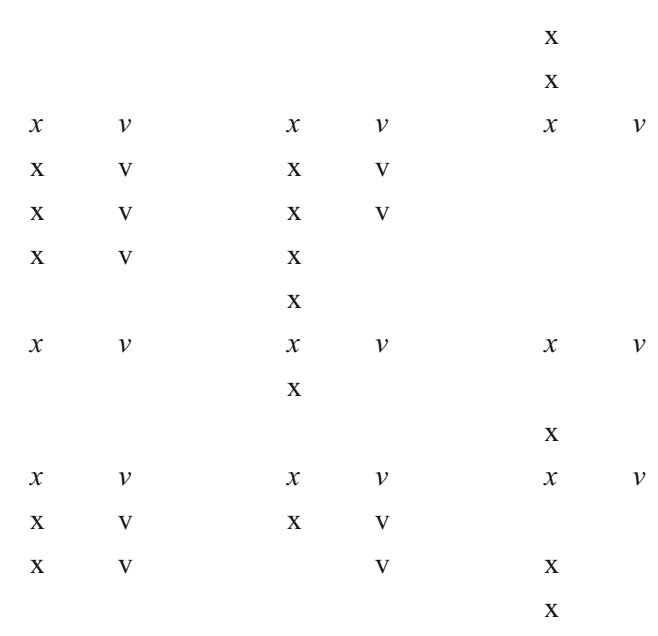

$\mathrm{X}$

$\mathrm{X}$

$\mathrm{X}$

$\mathrm{X}$

$\mathrm{X}$

$\mathrm{X}$

$\mathrm{X}$

$\mathrm{X}$

$\mathrm{X}$

$\mathrm{X}$

$\mathrm{X}$

V

X



X

x V

$\mathrm{X}$

V

X

X

$\mathrm{X}$

X V

V

V

X

$\mathrm{X}$

X

$\mathrm{X}$

$\mathrm{X}$

$\mathrm{x}$

$\mathrm{X}$

X

$\mathrm{X}$

$\mathrm{X}$ 
Table 2 (continued)

No List of all the fungi species isolated from the lake water and from the phyllosphere
Skanda

Kortowskie

Tyrsko

Water Phyllosphere Water Phyllosphere Water Phyllosphere

$48 \quad$ Kluyveromyces wickerhamii

Lachancea thermotolerans

50 Lachancea waltii

51 Lindnera jadinii (a: Candida utilis)

52 Lipomyces lipofer

53 Lodderomyces elongisporus

54 Magnusiomyces capitatus

55 Metschnikowia pulcherrima (a: Candida pulcherrima)

56 Millerozyma farinosa

57 Moniliella spathulata

58 Nakaseomyces bacillisporus

59 Nakazawae holstii

60 Pichia anomala

61 Pichia bispora

62 Pichia farinosa

63 Pichia jadinii

64 Pichia membranifaciens

65 Pichia polymorpha

66 Pichia subpeliculosa

67 Priceomyces carsonii

68 Rhodosporidium lusitaniae

69 Rhodosporidium malvinellum

70 Rhodosporidium sphaerocarpum (a: Rhodotorula glutinis)

71 Rhodotorula acheniorum

72 Rhodotorula muscilaginosa

73 Saccharomyces bayanus

74 Saccharomyces bisporus

75 Saccharomyces castellanii

76 Saccharomyces cerevisiae

77 Saccharomyces delbruecki

78 Saccharomyces fragilis

79 Saccharomyces microelipsoides

80 Saccharomyces rosei

81 Saccharomyces williamus

82 Saccharomycodes ludwigii

83 Saccharomycopsis capsularis

84 Saccharomycopsis fibuligera

85 Saccharomycopsis guttulata

86 Saccharomycopsis javanensis

87 Scheferomyces segobiensis

88 Schizosaccharomyces octosporus

89 Schwanniomyces occidentalis

90 Schwanniomyces polysporus

91 Sporidiobolus pararoseus

92 Tetrapisispora phaffi

93 Torulaspora delbruecki

94 Torulopsis molischiana

$\begin{array}{lll} & \\ \mathrm{x} & & \mathrm{x} \\ \mathrm{x} & \mathrm{V} & \mathrm{x} \\ \mathrm{x} & & \mathrm{x} \\ \mathrm{x} & \mathrm{V} & \mathrm{x} \\ \mathrm{x} & & \mathrm{x} \\ \mathrm{x} & & \mathrm{x} \\ & & \end{array}$

$\mathrm{x}$

$\mathrm{x}$

$\mathrm{X}$

$\mathrm{x}$

$\mathrm{x}$

$\mathrm{x}$

v

$\mathrm{x}$

$\mathrm{x}$

$\mathrm{x}$

$\mathrm{x}$

v

$\mathrm{x}$

$\mathrm{v}$

v

v

$\mathrm{x}$

$\mathrm{X}$

V

v

$\mathrm{x}$

$\mathrm{x}$

x

$x$

v

v

v

$x$

$\mathrm{x}$

X

x $\quad$ v

$\mathrm{x}$

v

V

X

x

$\mathrm{x}$

$\mathrm{x}$

$\mathrm{x}$

$\mathrm{x}$

$\mathrm{x}$ 
Table 2 (continued)

\begin{tabular}{|c|c|c|c|c|c|c|c|}
\hline \multirow[t]{2}{*}{ No } & \multirow{2}{*}{$\begin{array}{l}\text { List of all the fungi species isolated from the lake water and from the } \\
\text { phyllosphere }\end{array}$} & \multicolumn{2}{|l|}{ Skanda } & \multicolumn{2}{|c|}{ Kortowskie } & \multicolumn{2}{|l|}{ Tyrsko } \\
\hline & & Water & Phyllosphere & Water & Phyllosphere & Water & Phyllosphere \\
\hline 95 & Trichosporonoides spathulata & & $\mathrm{v}$ & $\mathrm{x}$ & $\mathrm{v}$ & & \\
\hline 96 & Wanderwaltozyma polyspora & & & & & $\mathrm{x}$ & \\
\hline 97 & Wanderwaltozyma yarowii & & & & & $\mathrm{x}$ & \\
\hline 98 & Wickerhamomyces bisporus & & & & & & \\
\hline 99 & Wickerhamomyces bovis & & & & & $\mathrm{x}$ & \\
\hline 100 & Yamadazyma akitaensis & & & & & $\mathrm{x}$ & \\
\hline 101 & Zygosaccharomyces baiili & & & $\mathrm{x}$ & & & \\
\hline 102 & Zygosaccharomyces mellis & $\mathrm{x}$ & $\mathrm{v}$ & & & & $\mathrm{v}$ \\
\hline 103 & Zygosaccharomyces rouxii & & & & & $\mathrm{x}$ & \\
\hline
\end{tabular}

Italic entries indicate that yeast species isolated from both types of reservoirs (lake waters and the phyllosphere)

\section{Discussion}

Rush vegetation plays an important role in the process of inhibiting nutrient inflow, depending on the effectiveness of surface effluents from the drainage basin. It is a natural ecotonic zone [26], with buffer properties against inflowing nutrients. Recreational use of lakes contributes to fragmentation and, in consequence, to the lack of continuity of the zone. This results in easier nutrient inflow to a water body and in water pollution [27]. The most common plants in this zone include Phragmites communis, Ceratophyllum demersum and Polygonum amphibium. Aquatic vegetation in the lacustrine littoral zone is often inhabited by different microorganisms, including microfungi $[12,28]$. Yeast present in the phyllosphere often compete with phytopathogens for nutrients, and they also inhibit their growth and development by taking in organic matter from the leaf surface. This is of special importance when the fungi isolated from the phyllosphere can pose a hazard to human health and when the submerged vegetation zone is in close vicinity to the places of recreation [1-3]. About 200 of the many yeast species occurring in the aquatic environment are pathogens $[23,25]$.

Rush vegetation has been used for years in bioindication of aquatic ecosystems. Its characteristic structure with an extensive absorption system enables absorption of various microelements from the environment, both harmful and necessary for the plant [29]. Therefore, species of rush plants in assemblies of plants, as well as aesthetic values, also play an important ecological role. The health condition of coastal and aquatic vegetation has an indirect impact on the life of the aquatic fauna, for which it is a shelter and breeding place [30].

As a reservoir of fungi potentially hazardous to humans, the phyllosphere serves as a filter in a water body which provides the first significant barrier for microfungi from the soil environment. When water ripples and washes the leaf surface, fungi cells may be washed down into surface water, posing a serious sanitary and epidemiological hazard. Korniłłowicz et al. [31] and Simi et al. [32] report that various species of fungi in the aquatic environment may derive from birds nesting nearby. However, no bird nests were found near the sampling sites in our study. The lakes which the surveys were conducted in are located within the administrative boundaries of the city, which results in reduced nesting in the coastal area. Fragments of the phyllosphere were collected during a period of intense exploitation of recreational and bathing sites located in the immediate vicinity of designated research areas.

Yeast and bacteria and/or moulds occur on leaf surface, forming aggregates or multicellular biofilms [33]. However, they are not the first group of microorganisms which settle the phyllosphere. This place is first settled by bacteria, which change the structure of cuticle and the lamina of the leaf. They are followed by yeast, with the filamentous fungi, which include numerous pathogens, being the last [28]. The moment of depositing and adhering of yeast on the lamina of the leaf usually occurs in summer, when the lamina surface is well developed. Fungi development is sometimes initiated by an increase in organic matter amount between spring and autumn, which is correlated with the plant growing season. The process of macrophyte decomposition indirectly increases the amount of biogenic elements, including nitrogen and phosphorus, thereby accelerating water eutrophication. Yeast floating in the pelagic zone in water under anthropopressure have higher enzymatic activity, increasing with the degree of eutrophication, which is directly associated with strain pathogenicity [3]. The presence of yeast, including potentially pathogenic species, has been confirmed by the findings of this study. Obtaining as many as 36 fungi species from the phyllosphere of Lake Skanda-which is highly eutrophicated - is worrying because up to eight of them belong to the genus Candida, which are important agents in aetiology of mycosis caused by Saccharomycetes. This can be demonstrated by the fact that the same species, such as 
Candida albicans, C. krusei and C. tropicalis, were found in clinical materials $[1,34]$ and at bathing sites in urban lakes $[1-3,35]$.

Selected water reservoirs differ from each other in the nature of the shoreline and the catchment area, or in the development of adjacent areas. Tyrsko lake, located in the northwest of Olsztyn, is characterised by the greatest landscape values. It is an area slightly transformed by man. Its shores are high and steep in places [36], and the state of water transparency is included in the second class of cleanliness, making it a great place for diving enthusiasts. An additional advantage of the lake is the lack of surface inflows and outflows. The second lake, Kortowskie, is located in the southwestern part of the city. It is a flow-through reservoir fed by five watercourses: the Starodworski, Parkowy and Leśny Stream, drainage line, and the Kortówka river, which is also its surface outflow [37]. It is a lake with an advanced level of eutrophication, intensively used for tourism and recreation. Its catchment has a forest-agricultural character. From the south-eastern side, it is surrounded by the gardens of the University of Warmia and Mazury and the infrastructure of the academic town with its recreation part (park, marina, water equipment rental, guarded swimming pool) [38]. The established Kortowski experiment has been in operation since 1959, consisting in removing pollutants to the Kortówka river with the help of hypolimnion waters [39]. According to research conducted in 2014 by Smoter et al. [40], the ecological status of the lake was assessed as poor (class IV water quality). The third lakeSkanda, is located on the south-eastern outskirts of Olsztyn [40]. Like Kortowskie lake, it belongs to reservoirs with an advanced degree of eutrophication, intensively used for recreational and tourist purposes [38]. Its shoreline is well developed, and its shores are quite varied, from flat through gently raised to steep [40], with visible traces of anthropopressure [38]. An important role is played by the runoff from agricultural areas, as well as pollution from two non-canalised farms located in the close proximity to the lake. The ecological state of the lake is classified as poor (class V of water quality) [40].

Considering the position of the isolated microfungi in the biosafety classification, it should be noted that the dominant group includes species of the BSL-2 group, i.e. potential human and other vertebrate pathogens [22, 23]. On the other hand, finding such a large number of yeast species inhabiting the littoral zone phyllosphere confirms that the zone acts as a filter for the lake catchment area [41].

\section{Conclusion}

Finding many potentially pathogenic yeast species in the lake littoral zone shows the huge human impact on the hydrosphere microbiological quality. Therefore, lake shores at bathing sites should be cleared of vegetation to prevent anthropogenic pollution from accumulating there. This study provides valuable complementary information on the natural composition of the littoral microbiota in water bodies.

Acknowledgements We would like to thank prof. Maria Dynowska for her valuable suggestions and remarks during the preparation of the manuscript.

Funding This study was funded by the Department of Microbiology and Mycology, Faculty of Biology and Biotechnology, University of Warmia and Mazury in Olsztyn (12.610.009-300).

\section{Compliance with ethical standards}

Conflict of interest The authors declare that they have no conflict of interest.

Ethical approval Ethics approval was not required.

Open Access This article is distributed under the terms of the Creative Commons Attribution 4.0 International License (http:// creativecommons.org/licenses/by/4.0/), which permits unrestricted use, distribution, and reproduction in any medium, provided you give appropriate credit to the original author(s) and the source, provide a link to the Creative Commons license, and indicate if changes were made.

\section{References}

1. Biedunkiewicz A (2007) Fungi in the sanitary-epidemiological assessment of the chosen bathing beach. In: Garbacz J (ed) Diagnosing the state of the environment. Research methods - forecasts. t. I. Prace Komisji Ekologii i Ochrony Środowiska Bydgoskiego Towarzystwa Naukowego. BTN, Bydgoszcz, pp 107-121 [In Polish]

2. Biedunkiewicz A, Baranowska E (2011) Yeasts and yeast-like fungi as an element of purity assessment of surface waters. Pol J Environ Stud 20:267-274

3. Biedunkiewicz A, Dynowska M, Ejdys E, Sucharzewska E (2013) Species diversity of yeast-like fungi in some eutrophic lakes in Olsztyn. Acta Mycol 48:61-71

4. Biedunkiewicz A, Góralska K (2016) Microfungi potentially pathogenic for humans reported in surface waters utilized for recreation. CLEAN - Soil, Air, Water 44:599-609. https://doi.org/10.1002/ clen.201500696

5. Biedunkiewicz A, Ozimek T (2009) Qualitative and quantitative changes of potentially pathogenic fungi in hydrophyte wastewater treatment plant (case study in Nowa Słupia, Poland). Pol J Environ Stud 18:161-166

6. Adamska I, Czerniawska B (2009) Parasitic fungi on rushes. Prog Plant Prot 49:173-176 [In Polish]

7. Czerniawska B, Adamska I (2009) Parasitic fungi on sedges. Prog Plant Prot 49:187-190 [In Polish]

8. Kowalik M (2012) Phyllosphere mycobiota on garden pond plants. Acta Mycol 47:11-19

9. Mazurkiewicz-Zapałowicz K (2009) Phylloshere microorganosms and state of health of species of Carex in the Drawa National Park. Phytopathol 51:13-20

10. Mazurkiewicz-Zapałowicz K, Ładczuk D, Wolska M (2012) Phytopathogenic microorganisms colonizing the common reed 
[Phragmites australis (Cav.) Trin. Ex Steud.]. Prog Plant Prot 52: 82-87

11. Mazurkiewicz-Zapałowicz K, Wróbel M, Silicki A, Wolska M (2006) Studies on phytopathogenic and saprotrophic fungi in rush associations of Lake Glinno (NW Poland). Acta Mycol 41:125-138

12. Nowacka K, Kulesza K, Glinka P, Sucharzewska E, Dynowska M (2018) The phyllosphere as a little-known reservoir of the Fusarium genus, a fungi of importance to medical mycology. Ann Parasit 64: 225-228. https://doi.org/10.17420/ap6403.156

13. Osono T, Bhatta BK, Takeda H (2004) Phyllosphere fungi on living and decomposing leaves of giant dogwood. Mycoscience 45:3541. https://doi.org/10.1007/S10267-003-0155-7

14. Czeczuga B, Mazalska B, Godlewska A, Muszyńska E (2005) Aquatic fungi growing on dead fragments of submerged plants. Limnol 35:283-297

15. Xumeng G, Ningning Z, Gregory CP, Jianfeng X (2012) Growing Lemna minor in agricultural wastewater and converting the duckweed biomass to ethanol. Bioresource Technology 124:485-488. https://doi.org/10.1016/j.biortech.2012.08.050

16. Kucharska K, Wachowska U (2014) Crop plant microbiota. Post Mikrobiol 53:352-359 [In Polish]

17. Hagler AN, Ribeiro JRA, Pinotti T, Branda LR, Pimenta RS, Lins U, Lee CF, Hsieh CW, Lachances MA, Rosa CA (2013) Wickerhamiella slavikovae sp. nov. and Wickerhamiella goesii sp. nov., two yeast species isolated from natural substrates. Int J Syst Evol Microbiol 63:3099-3103. https://doi.org/10.1099/ijs.0. 051953-0

18. Brighigna L, Gori A, Gonnelli S, Favilli F (2000) The influence of air pollution on the phyllosphere microflora composition of Tillandsia leaves (Bromeliaceae). Rev Biol Trop 48:51-17

19. Matavulj MN, Vulikiã N, Gojkoviã I, Karaman MA (2005) Conditionally pathogenic fungi in recreational waters. Proc Nat Sci. Matica Srpska Novi Sad. 109:149-160. https://doi.org/10. 2298/ZMSPN0519149M

20. Medeiros AO, Missagia BS, Brandão LR, Callisto M, Barbosa FAR, Rosa CA (2012) Water quality and diversity of yeasts from tropical lakes and rivers from the Rio Doce Basin in southeastern Brazil. Braz J Microbiol 43:1582-1594. https://doi.org/10.1590/ S1517-83822012000400004

21. Pietryczuk A, Cudowski A, Hauschild T (2014) Effect of trophic status in lakes on fungal species diversity and abundance. Ecotox Environ Safe 109:32-37. https://doi.org/10.1016/j.ecoenv.2014.07. 032

22. De Hoog GS (1996) Risk assessment of fungi reported from humans and animals. Mycoses 39:407-417

23. De Hoog GS, Guarro J, Gene J, Figuerras MJ (2000) Atlas of clinical fungi. Centraalbureau voor Schimmelcultures/Universitat Rovira and Virgili, Reus

24. Kurtzman CP, Fell JW (2000) The Yeast. A taxonomic study4 th edn. Elsevier, Amsterdam

25. Kurtzman CP, Fell JW, Boekhout T (2011) The yeasts: a taxonomic study5th edn. Elsevier, Tokyo
26. Pelechaty M, Pronin E (2015) The role of aquatic and rush vegetation in the functioning of lakes and assessment of the state of their waters. Stud Limnol Telmatol 9:25-34 [In Polish]

27. Krupska J, Pełechaty M, Pukacz A, Ossowski P (2012) Effects of grass carp introduction on macrophyte communities in a shallow lake. Oceanol Hydrobiol Stud 41:35-40

28. Whipps JM, Hand P, Pink D, Bending GD (2008) Phyllosphere microbiology with special to reference diversity and plant genotype. J Appl Microbiol 105:1744-1755. https://doi.org/10.1111/j. 1365-2672.2008.03906.x

29. Rabajczyk A, Jóźwiak AM (2008) Possibilities of using macrophytes as bioindicators of heavy metals deposited in bottom sediments. Monitoring of the Natural Environment. Kielce 9:19-26 [In Polish]

30. Załachowski W (1997) Fishes. PWN, Warszawa

31. Korniłłowicz-Kowalska T, Kitkowski I, Bohacz J, Kwiatkowska E (2018) Fungal frequency and diversity in the nests of wetland birds from Poland: relationships between birds, nest properties and inhabiting fungi. Avian Biol Res 11:245-262. https://doi.org/10. 3184/175815618X15360537405342

32. Simi WB, Leite-Jr DP, Paula CR, Hoffmann-Santos HD, Takahara DT, Hahn RC (2019) Yeast and filamentous fungi in Psittacidae and birds of prey droppings in Midwest region of Brazil: a potential hazard to human health. Braz J Biol 79:414-422. https://doi.org/ 10.1590/1519-6984.181192

33. Lindow SE, Brandl MT (2003) Microbiology of the phyllosphere. Appl Environ Microbiol 69:1875-1883

34. Dynowska M, Ejdys E, Biedunkiewicz A, Kubiak D, Sucharzewska E, Rosłan M (2014) Yeasts isolated from frequently in-patients and out-patients. Ann Parasit 60:199-206

35. Biedunkiewicz A, Silicki A, Mazurkiewicz-Zapałowicz K (2007) Yeast-like fungi in selected bath of Szczecin. Limnol Rev 3:3-10

36. Gadomska W (2006) Landscape values of Olsztyn lakes and their development. PTiE, Ecological Engineering, 15, Shaping and environmental protection, Natural, technical and socio-economic conditions, Warszawa: 27-33 [In Polish]

37. Dunalska J, Wiśniewski G, Cz M (2007) Assessment of multi-year (1956-2003) hypolimnetic withdrawal from Lake Kortowskie, Poland. Lake and Reservoir Management 23:377-387

38. Furgała-Selezniow G, Cudnik M, Skrzypczak A, Mamcarz A (2011) Changes in tourism space of lakes influenced by recreational use of lake shores: a case study of Skanda and Kortowskie Lakes. In: Durydiwka M, Duda-Gromada K (eds.) The tourism space, factors, diversity, changes. Warsaw University, Faculty of Geography and Regional Studies, pp: 263-270 [In Polish]

39. Dzika E, Kuształa M, Kozłowski J (2008) Metazoan parasite fauna of fish species from Lake Kortowskie. Arch Pol Fish. 16:75-86

40. Smoter K, Borsiak D, Dowejko A, Jędrychowska G (2015) Assessment of the water of the lakes examined in 2014. Wojewódzki Inspektorat Ochrony Środowiska w Olsztynie [In Polish]

41. Dynowska M (1995) Yeast and yeast-like fungi as pathogens and bioindicators of aquatic ecosystems. Studia i Materiały WSP, Olsztyn 77 [In Polish] 